Biol. Stud. 2021; 15(3): 51-60 • DOI: https://doi.org/10.30970/sbi.1503.660

www.http://publications.Inu.edu.ua/journals/index.php/biology

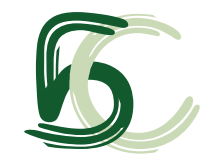

UDC: 582.32

\title{
ACCUMULATION OF HEAVY METALS AND ANTIOXIDANT DEFENSE SYSTEM IN THE GAMETOPHYTE OF DIDYMODON RIGIDULUS HEDW. IN AREAS WITH HIGH TRAFFIC LOADS
}

\author{
A. I. Polishchuk ${ }^{\oplus,}$ H. L. Antonyak®0 \\ Ivan Franko National University of Lviv, 4 Hrushevskyi St., Lviv 79005, Ukraine
}

Polishchuk, A.I., \& Antonyak, H.L. (2021). Accumulation of heavy metals and antioxidant defense system in the gametophyte of Didymodon rigidulus Hedw. in areas with high traffic loads. Studia Biologica, 15(3): 51-60 • DOI: https://doi.org/10.30970/sbi.1503.660

Background. Various modes of transport are among the main sources of environmental pollution with heavy metals and other pollutants. Bryophytes are known to accumulate heavy metals; however, metabolic changes in mosses under conditions of metal accumulation have not been extensively studied. The aim of this article was to analyze the accumulation of heavy metals, the process of lipid peroxidation (LPO) and the activity of enzymes of the antioxidant system in Didymodon rigidulus Hedw. moss collected in urban areas with an intense road and railway transport load.

Materials and Methods. Gametophyte shoots were collected at three sampling sites in the city of Lviv (Ukraine). Site 1 was selected in a park zone, which was considered a control one; sites 2 and 3 were selected in areas with heavy road and rail traffic, respectively. Concentrations of chromium $(\mathrm{Cr})$, nickel $(\mathrm{Ni})$, lead $(\mathrm{Pb})$, and zinc $(\mathrm{Zn})$ in the moss material were determined by atomic absorption spectrophotometry. The levels of LPO products, namely lipid hydroperoxides and thiobarbituric acid reactive substances (TBARS), as well as superoxide dismutase (SOD) and catalase activities, were determined by standard methods. The results were processed using the methods of variation statistics.

Results. Moss $D$. rigidulus growing in the park area (site 1) accumulated metals in the following order of decreasing concentration: $\mathrm{Zn}>\mathrm{Cr}>\mathrm{Ni}>\mathrm{Pb}$. Gametophyte shoots of D. rigidulus collected at site 2 accumulated higher levels of $\mathrm{Pb}, \mathrm{Zn}$ and $\mathrm{Ni}(2.27,1.78$ and 1.45 times, respectively), and at site 3 , higher levels of $\mathrm{Pb}$ and $\mathrm{Zn}$ (1.8 and 1.67 times, respectively) compared to gametophytes collected in the park zone. In the moss samples from these sites, no significant differences in $\mathrm{Cr}$ content were found as compared to the

() 2021 A. I. Polishchuk and H. L. Antonyak. Published by the Ivan Franko National University of Lviv on behalf оf Біологічні Студії / Studia Biologica. This is an Open Access article distributed under the terms of the Creative Commons Attribution 4.0 License which permits unrestricted reuse, distribution, and reproduction in any medium, provided the original work is properly cited.

ISSN 1996-4536 (print) • ISSN 2311-0783 (on-line) • Біологічні Студії / Studia Biologica • 2021 • Том 15 / № 3 • С. 51-60 
control. The concentration of lipid hydroperoxides in the moss sampled at sites 2 and 3 was 4.26 and 3.75 times higher, respectively, compared to the control, and TBARS production was more intense in plant material from site 2 than from the control site. SOD and catalase activities were considerably increased in D. rigidulus moss from site 2 compared with those from the control area; however, the activity of both enzymes in the moss samples from site 3 did not significantly exceed the control levels.

Conclusions. Both road and rail traffic loads contribute to the accumulation of heavy metals, especially $\mathrm{Zn}$ and $\mathrm{Pb}$, in $D$. rigidulus moss growing in the surrounding areas. Under such conditions, LPO process is stimulated, which is more pronounced in moss growing in the area with heavy road traffic. The increased activity of antioxidant enzymes (SOD and catalase) in moss growing in this area can play an important role in protecting bryophyte cells against metal-induced oxidative stress under conditions of intense metal accumulation.

Keywords: bryophytes, Didymodon rigidulus, heavy metals, lipid peroxidation, antioxidant system, urban ecosystems

\section{INTRODUCTION}

Various modes of transport are known to be among the main sources of environmental pollution. In Ukraine, road transport accounts for an average of $34 \%$ of the total releases of polluting substances from various sources, but in many regions emissions from motor vehicles prevail over emissions from stationary sources [3, 19, 30]. Of all the pollutants released into the atmosphere as a result of transport activities, heavy metals belong to the most hazardous ones [18, 24]. Among the known mechanisms that mediate the toxicity of heavy metals in biological systems is the formation of reactive oxygen species capable of interacting with cellular biomolecules. This is accompanied by stimulation of the process of lipid peroxidation (LPO), inactivation of sulfhydryl groups of proteins, damage to cell membranes and nucleic acids [7].

Some groups of terrestrial vegetation, including bryophytes, are highly resistant to the toxicity of heavy metals and can accumulate these substances in large concentrations [28]. Bryophytes are often used in the environmental assessment of the atmosphere due to their ability to absorb pollutants, mainly from air and precipitation $[17,21$, 28]. The resistance of mosses to metal toxicity is largely due to their physiological and metabolic characteristics [28]. However, the relationship between the intensity of metal uptake and the activity of defense systems in bryophyte cells has not been studied completely.

The aim of this study was to investigate the level of accumulation of heavy metals, intensity of LPO process and the state of the antioxidant system in the bryophyte Didymodon rigidulus Hedw. collected in areas of road and railway traffic loads within the territory of Lviv (Ukraine).

\section{MATERIALS AND METHODS}

Study area. In the course of the study, three separate sites were selected in areas with different levels of anthropogenic pressure within the city of Lviv. Site 1 was chosen in the central part of Sknylivskyi Park $\left(49^{\circ} 48^{\prime} 55^{\prime \prime} \mathrm{N}, 23^{\circ} 57^{\prime} 59^{\prime \prime} \mathrm{E}\right)$ located in Zaliznychnyi District of the city. The park covers an area of almost 57.7 hectares; its central part is

ISSN 1996-4536 (print) • ISSN 2311-0783 (on-line) • Біологічні Студії / Studia Biologica • 2021 • Том 15 / № 3 • C. 51-60 
almost unaffected by technogenic factors. Therefore, this site was considered as a control plot. Sites 2 and 3 were selected in Frankivskyi District of Lviv, in areas subject to anthropogenic impact. Site 2 was chosen in the territory adjacent to Kulparkivska Street, near its junction with Okruzhna and Antonovycha streets $\left(49^{\circ} 49^{\prime} 30.5^{\prime \prime} \mathrm{N}, 2^{\circ} 59^{\prime} 23.4^{\prime \prime} \mathrm{E}\right)$. Site 3 was selected at the end of Eugene Konovalets Street $\left(49^{\circ} 49^{\prime} 23.5^{\prime \prime} \mathrm{N}, 2^{\circ} 59^{\prime} 31.6^{\prime \prime} \mathrm{E}\right)$ adjacent to the Lviv-Khodoriv railway line; this area is exposed to railway loads, but it is virtually unaffected by road traffic.

Analysis of moss material. The bryophyte Didymodon rigidulus is a member of the family Pottiaceae, class Bryopsida. It belongs to calciphilic species, which are distributed on substrates with a high content of calcium carbonate. The species is often found on partially shaded surfaces of rocks and stones, as well as on artificial substrates containing calcite, such as concrete $[9,27]$. In natural ecosystems, $D$. rigidulus occurs on the surface of limestone and loess deposits, limestone blocks and soils. It has also been found as a component of the biological crust on the soil surface in arid and semi-arid ecosystems [22]. In urban ecosystems, D. rigidulus can be found on old building walls, limestone fences, lawns, sidewalks, and asphalt pavements. The species is common on the territory of Ukraine and other countries [4, 9, 10, 27].

Gametophyte shoots were collected at sampling sites 1-3 and analyzed for metal content, levels of lipid peroxidation products and antioxidant system enzyme activities. Moss material was sampled in triplicate at each sampling site. Sampling and preparation of moss material for analysis were carried out using standard methods [29].

Concentrations of chromium ( $\mathrm{Cr}$ ), nickel (Ni), lead $(\mathrm{Pb})$ and zinc $(\mathrm{Zn})$ in moss gametophytes were determined by the method of atomic absorption spectrophotometry. The plant material was mineralized with $\mathrm{HNO}_{3}$ and $\mathrm{H}_{2} \mathrm{O}_{2}$ prior to analysis [17]. The measurements were performed using a C-115PK Selmi atomic absorption spectrometer (Ukraine). Metal concentrations were expressed in milligrams per $1 \mathrm{~kg}$ of dry weight of the samples.

Analysis of the level of lipid hydroperoxides in moss tissues was carried out by a method based on spectrophotometric measurement $(\lambda=480 \mathrm{~nm})$ of products formed in the tissue extracts in the presence of ammonium ferrous sulfate hexahydrate (Mohr's salt), hydrochloric acid, and ammonium thiocyanate [15]. Prior to reaction, proteins in homogenates were precipitated with trichloroacetic acid, and lipids were extracted with ethanol. To determine the concentration of thiobarbituric acid reactive substances (TBARS) in the moss material, the colorimetric method with thiobarbituric acid (TBA) was used [5].

Superoxide dismutase (SOD, EC 1.15.1.1) activity was analyzed using a non-enzymatic method based on reduction of nitro-blue tetrazolium in the presence of NADH and phenazine methosulfate $[11,16]$. Catalase (EC 1.11.1.6) activity was determined by a spectrophotometric assay [1] recording the decrease in optical density at $240 \mathrm{~nm}$ during the decomposition of $\mathrm{H}_{2} \mathrm{O}_{2}$. Protein concentration was determined by the method of Lowry et al. (1951) [13].

The results were processed by methods of variation statistics [31]. Conducting a statistical analysis of the results, the arithmetic mean and its standard deviation ( $\mathrm{M} \pm$ S.D.) were calculated. When comparing data groups, the significance of differences was assessed using the Student's $t$-test. Differences between data groups obtained at each sampling site were considered significant at $p<0.05$.

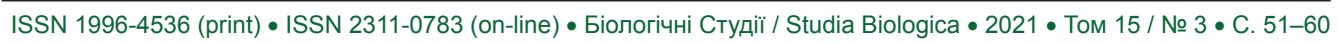




\section{RESULTS AND DISCUSSION}

The results shown in Fig. 1, demonstrate the accumulative capacity of Didymodon rigidulus moss for four heavy metals, which are often found in high concentrations in the environmental components of industrial cities. It has been found that the content of $\mathrm{Cr}$, $\mathrm{Ni}, \mathrm{Pb}$ and $\mathrm{Zn}$ in the $\mathrm{D}$. rigidulus gametophyte as a whole reaches values of the same order of magnitude as in other previously studied epilithic mosses, such as Schistidium apocarpum and Rhynchostegium murale [20]. Depending on the level of their accumulation in $D$. rigidulus shoots, the analyzed metals can be arranged in the following order of decreasing concentration: $\mathrm{Zn}>\mathrm{Cr}>\mathrm{Ni}>\mathrm{Pb}$. However, the metal content in $D$. rigidulus varied according to the location of the sampling sites. The most significant differences were found in the concentrations of $\mathrm{Pb}$ and $\mathrm{Zn}$ in moss gametophytes collected at sites 2 and 3, compared with moss material from the park area (site 1). In particular, the concentration of $\mathrm{Pb}$ and $\mathrm{Zn}$ in D. rigidulus moss collected from Kulparkivska Street (site 2) was considerably higher (2.27 and 1.78 times, respectively, $p<0.05)$ than in moss sampled in Sknylivskyi Park (site 1). In the gametophyte of moss taken at site 3, the concentrations of these metals were 1.8 and 1.67 times higher, respectively, compared to the levels recorded in moss collected at the control site. The concentration of $\mathrm{Ni}$ in $D$. rigidulus moss from sites 2 and 3 also showed an upward trend compared with plants collected from the park area, but the difference between the results was statistically significant (1.45 times, $p<0.05)$ only for the moss sampled at site 2 . The $\mathrm{Cr}$ concentration did not change in the moss collected from sites 2 and 3 as compared to the control.

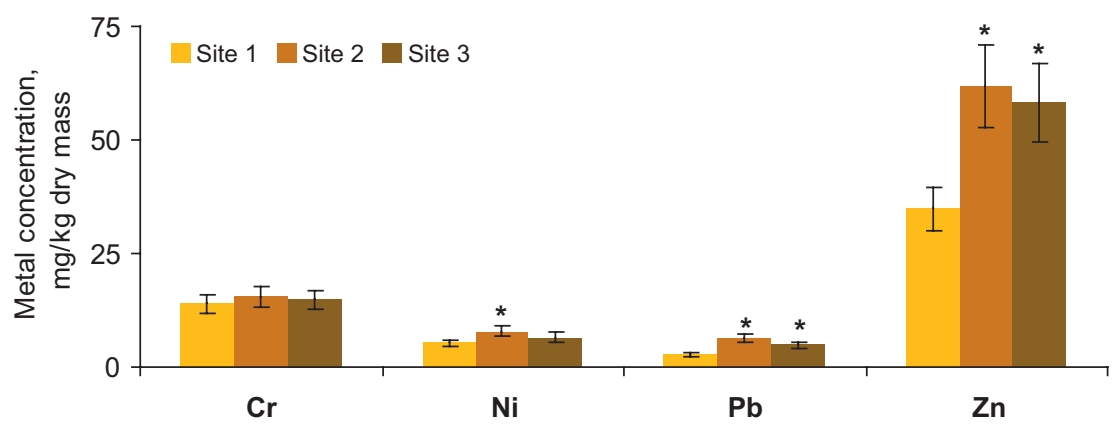

Fig. 1. Concentration of heavy metals in the gametophyte of Didymodon rigidulus collected at three sampling sites in the territory of Lviv (site 1 - Sknylivskyi Park; site 2 - Kulparkivska Street; site 3 - Eugene Konovalets Street)

Comment: * statistically significant differences between the analyzed indices (means \pm S.D.) in moss gametophytes sampled at site 1 (control) and at sites 2 and 3, p<0.05

Рис. 1. Концентрація важких металів у гаметофіті моху Didymodon rigidulus, зібраного на трьох ділянках на території м. Львова (ділянка 1 - Скнилівський парк; ділянка 2 - вулиця Кульпарківська; ділянка 3 - вулиця Євгена Коновальця)

Примітка: * - статистично вірогідні відмінності між аналізованими показниками (M \pm S.D.) у зразках моху, відібраних на ділянці 1 (контроль) та на ділянках 2 і 3, p <0,05

Elevated metal concentrations in the gametophyte of moss collected at sites 2 and 3 correspond to the intensity of traffic in these areas. In particular, Kulparkivska Street (site 2) belongs to the main thoroughfares of Lviv and is constantly loaded with passing cars, trucks and buses. According to our observations, the traffic intensity on this stretch of the street averages 1100 vehicles per hour in the daytime. Site 3 is located in close

ISSN 1996-4536 (print) • ISSN 2311-0783 (on-line) • Біологічні Студії / Studia Biologica • 2021 • Том 15 / № 3 • С. 51-60 
proximity to the railway line used for various types of rail transportation (passenger trains and freight trains). Taking into account the fact that both road and rail transport are potential sources of heavy metal pollution $[6,12,34,36]$, the increased level of $Z n$, $\mathrm{Pb}$ and $\mathrm{Ni}$ accumulation in $\mathrm{D}$. rigidulus moss can be associated with high concentrations of metals in atmosphere at sites 2 and 3. A number of other studies have shown elevated levels of $\mathrm{Zn}, \mathrm{Pb}$, and other heavy metals in the soils of roadside and railway-side areas, as well as in tissues of vascular plants growing in the adjacent territories [6, 12, 33].

Studies conducted on terrestrial plants have shown that heavy metal pollution is often associated with an increased rate of formation of reactive oxygen species (ROS) and lipid peroxidation products in plant cells $[2,23,25,26]$. The results of this study indicate the activation of LPO processes also in $D$. rigidulus bryophyte collected in areas exposed to road and rail traffic loads (Fig. 2). Namely, gametophytes of $D$. rigidulus collected at site 2 were characterized by higher concentrations of lipid hydroperoxides and TBARS (4.25 and 1.48 times, respectively), and moss samples from site 3 had a higher content of lipid hydroperoxides ( 3.75 times) compared with those collected at the control site. However, no significant changes in the TBARS level in moss gametophytes collected at site 3 were observed as compared to the control. These data may indicate a lesser degree of metabolic damage as a result of a lower level of metal accumulation in $D$. rigidulus shoots in the railway area compared to moss collected from area with heavy road traffic.

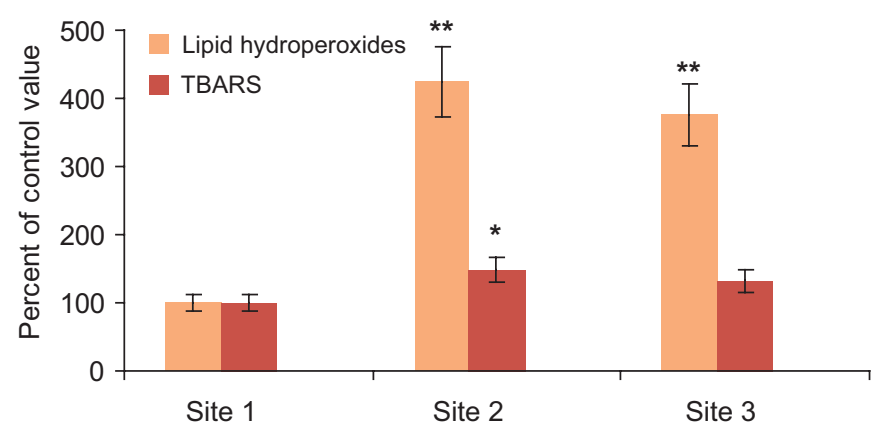

Fig. 2. The level of lipid peroxidation products (lipid hydroperoxides and thiobarbituric acid reactive substances (TBARS)) accumulation in the gametophyte of Didymodon rigidulus collected in the studied areas in the territory of Lviv

Comment: 1) in this and the following figures, data are expressed as a percentage of the control value (means \pm S.D.); 2$){ }^{*},{ }^{* *}$ statistically significant differences between samples taken at site 1 (control) and at sites 2 and $3\left({ }^{*} p<0.05 ;{ }^{* *} p<0.01\right)$

Рис. 2. Рівень накопичення продуктів пероксидного окиснення ліпідів (гідропероксиди ліпідів і речовини, що реагують з тіобарбітуровою кислотою (ТБК-активні продукти)) в гаметофріті моху Didymodon rigidulus, зібраного на досліджуваних ділянках у м. Львові

Примітки: 1) на цьому та наступному рисунках результати виражені у відсотках від контрольного значення (M \pm S.D.); 2) * ** - статистично вірогідні відмінності між зразками, відібраними на ділянці 1 (контроль) і на ділянках 2 і 3 ( * - p <0,05; ** $-p<0,01)$

It is known that under stressful conditions, including those associated with exposure to heavy metals, the antioxidant defense system plays an important role in plant tissues [8, 23, 25, 35]. Antioxidant enzymes and non-enzymatic components of the antioxidant system counteract the accumulation of LPO products in the cell compartments and in the apoplast. The results of this study show that moss material taken at site 2 is characterized by an increased SOD and catalase activities $(p<0.05)$ compared with moss gametophytes sampled in the park area (site 1) (Fig. 3). 


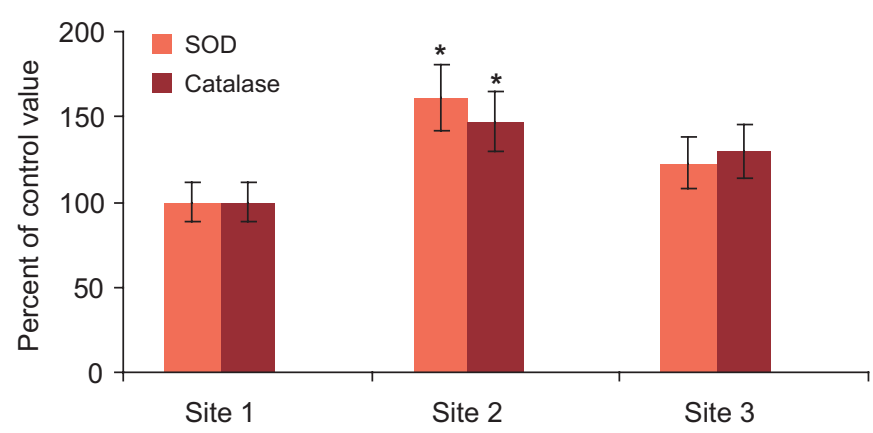

Fig. 3. Superoxide dismutase (SOD) and catalase activities in the gametophyte of Didymodon rigidulus collected in the study areas in the territory of Lviv

Comment: enzyme activities in moss sampled at site 1 (control) were as follows: $0.401 \pm 0.042$ arbitrary units/min mg protein (SOD); $5.45 \pm 0.62 \mu \mathrm{mol} \mathrm{H}_{2} \mathrm{O}_{2} / \mathrm{min}$ mg protein (catalase)

Рис. 3. Супероксиддисмутазна (СОД) і каталазна активність у гаметофіті моху Didymodon rigidulus, зібраного на досліджуваних ділянках у м. Львові

Примітка: активність ензимів у зразках моху, відібраних на ділянці 1 (контроль), становила: $0,401 \pm 0,042$ умовних одиниць/хв мг білка (СОД); $5,45 \pm 0,62$ мкмоль $\mathrm{H}_{2} \mathrm{O}_{2} /$ хв мг білка (каталаза)

Activation of antioxidant enzymes in $D$. rigidulus gametophytes may represent an adaptive response of moss cells to an intense ROS production caused by the accumulation of heavy metals. As it is known, SOD catalyzes the conversion of a reactive superoxide anion radical $\left(\mathrm{O}_{2}^{--}\right)$to hydrogen peroxide, which can subsequently decompose into water and oxygen mainly with the aid of catalase [14]. Consequently, these enzymes play an important role in protecting cells from the development of oxidative stress caused by the formation of ROS and LPO products. However, the activities of SOD and catalase in the moss material from sampling site 3 did not demonstrate any significant differences compared to the control. This indicates less pronounced metabolic changes in plants growing in the territory adjacent to the railway than in the area with heavy road traffic. At the same time, other components of the defense system may be involved in counteracting the development of oxidative stress in the gametophytes of moss growing at site 3. In addition to SOD and catalase, the detoxification of ROS and LPO products with the participation of non-enzymatic antioxidants and the activation of the glutathione system are also important links in the cellular defense mechanism [32]. All of these components of the antioxidant system together can participate in the protection of bryophyte cells from metal toxicity and are important for ensuring their resistance to metal contamination in areas with high traffic loads.

\section{CONCLUSIONS}

Based on the results obtained, it can be concluded that both road and rail traffic loads contribute to the accumulation of heavy metals in the gametophytes of $D$. rigidulus growing in the adjacent territories. This is especially true for $\mathrm{Zn}$ and $\mathrm{Pb}$, which intensively accumulates in moss tissues in the conditions of environmental pollution by emissions from both road and railway transport. The accumulation of metals in moss gametophytes is accompanied by a strong increase in the concentration of LPO products, which indicates the stimulation of ROS formation under the influence of heavy metals. Under these conditions, activation of antioxidant enzymes, such as SOD and catalase, can protect bryophyte cells against metal-induced oxidative stress. At the same time, 
the increased activity of antioxidant enzymes may play a role in the adaptation of $D$. rigidulus to heavy metal contamination in areas exposed to high traffic loads.

\section{COMPLIANCE WITH ETHICAL STANDARDS}

Conflict of interest: The authors declare that the study was conducted in the absence of any commercial or financial relationship that could be construed as a potential conflict of interest.

Animal rights: This article does not include animal studies.

\section{AUTHOR CONTRIBUTIONS}

Conceived and planned the experiments [A. I. P. \& H. L. A.]; conducted experiments and data collection [A. I. P.]; both authors analyzed and discussed the results and contributed to the final manuscript.

1. Aebi, H.E. (1983). Catalase. In: H.U. Bergmeyer (Ed.), Methods of enzymatic analysis (pp. 273-286). Weinheim, Germany: Verlag Chemie.

Googl Scholar

2. Antonyak, H.L., Mamchur, Z.I., Pershyn, O.I., Bubys, O.E., \& Kordosh, T.V. (2015). Biolohichna dostupnist' metaliv ta yikh akumulyatsiya $v$ tkanynakh roslyn [Bioavailability of metals and their accumulation in plant tissues]. Bulletin of Problems of Biology and Medicine, 2(123), 11-16. [In Ukrainian]

Coogle Scholar

3. Antonyak, H., Mamchur, Z., Polishchuk, A., Lesiv, M., \& Hoivanovych, N. (2020). Environmental impact of road transport. In: A. Krynski, G. Kamtoh Tebug, S. Voloshanska (Eds.), Sustainable Development and Human Health (pp. 61-74). Czestochowa: Publishing House of Polonia University "Educator".

4. Boiko, M.F. (2008). Cheklist Mokhopodibnykh Ukrayiny [A Checklist of Bryobionta of Ukraine]. Kherson: Ailant. [In Ukrainian]

Google Scholar

5. Chen, T., \& Zhang, B.L. (2016) Measurements of proline and malondialdehyde contents and antioxidant enzyme activities in leaves of drought stressed cotton. Bio-Protocol, 6(17), e1913.

Crossref $\bullet$ Google Scholar

6. Chen, Z., Wang, K., Ai, Y. W., Li, W., Gao, H., \& Fang, C. (2014). The effects of railway transportation on the enrichment of heavy metals in the artificial soil on railway cut slopes. Environmental Monitoring and Assessment, 186(2), 1039-1049.

Crossref $\bullet$ PubMed $\bullet$ Google Scholar

7. Fryzova, R., Pohanka, M., Martinkova, P., Cihlarova, H., Brtnicky, M., Hladky, J., \& Kynicky, J. (2018). Oxidative stress and heavy metals in plants. Reviews of Environmental Contamination and Toxicology, 245, 129-156.

Crossref $\bullet$ PubMed $\bullet$ Google Scholar

8. Gill, S.S., \& Tuteja, N. (2010). Reactive oxygen species and antioxidant machinery in abiotic stress tolerance in crop plants. Plant Physiology and Biochemistry, 48(12), 909-930.

Crossref $\bullet$ PubMed $\bullet$ Google Scholar

9. Godovičová, K. (2017). Bryophytes of the botanical garden of the Comenius University in Bratislava. Acta Botanica Universitatis Comenianae, 52, 29-34.

Google Scholar

10. Hodgetts, N.G., Söderström, L., Blockeel, T.L., Caspari, S., Ignatov, M.S., Konstantinova, N.A., Lockhart, N., Papp, B., Schröck, C., Sim-Sim, M., Bell, D., Bell, N.E., Blom, H.H., BruggemanNannenga, M.A., Brugués, M., Enroth, J., Flatberg, K.I., Garilleti, R., Hedenäs, L., Holyoak, D.T., 
Hugonnot, V., Kariyawasam, I., Köckinger, H., Kučera, J., Lara, F., \& Porley, R.D. (2020). An annotated checklist of bryophytes of Europe, Macaronesia and Cyprus. Journal of Bryology, 42(1), 1-116.

Crossref $\bullet$ Google Scholar

11. Kakkar, P., Das, B., \& Viswanathan, P. (1984). A modified spectrophotometric assay of superoxide dismutase. Indian Journal of Biochemistry and Biophysics, 21(2), 130-132.

PubMed • Google Scholar

12. Li, D., \& Liao, Y. (2018). Spatial characteristics of heavy metals in street dust of coal railway transportation hubs: a case study in Yuanping, China. International Journal of Environmental Research and Public Health, 15(12), 2662.

Crossref • PubMed $\bullet$ PMC $\bullet$ Google Scholar

13. Lowry, O.H., Rosebrough, N.J., Farr, A.L., \& Randall, R.J. (1951). Protein measurement with the Folin phenol reagent. Journal of Biological Chemistry, 193(1), 265-275.

Crossref $\bullet$ Google Scholar

14. Mhamdi, A., Noctor, G., \& Baker, A. (2012). Plant catalases: peroxisomal redox guardians. Archives of Biochemistry and Biophysics, 525(2), 181-194.

Crossref $\bullet$ PubMed $\bullet$ Google Scholar

15. Mironchik, V.V. (1984). Method for determination of lipid hydroperoxides in biological tissues. USSR author's certificate, No. 1084681. Appl. 07/08/82; publ. 04/07/84, Bul. No. 13.

16. Nishikimi, M., Appaji, N., \& Yagi, K. (1972). The occurrence of superoxide anion in the reaction of reduced phenazine methosulfate and molecular oxygen. Biochemical and Biophysical Research Communications, 46(2), 849-854.

Crossref $\bullet$ Google Scholar

17. Ogunkunle, C.O., Ziyath, A.M., Rufai, S.S., \& Fatoba, P.O. (2016). Surrogate approach to determine heavy metal loads in a moss species - Barbula lambaranensis. Journal of King Saud University - Science, 28(2), 193-197.

Crossref $\bullet$ Google Scholar

18. Pan, L., Wang, Y., Ma, J., Hu, Y., Su, B., Fang, G., Wang, L., \& Xiang, B. (2018). A review of heavy metal pollution levels and health risk assessment of urban soils in Chinese cities. Environmental Science and Pollution Research International, 25(2), 1055-1069.

Crossref • PubMed • Google Scholar

19. Pershakov, V.M., Belyatinsky, A.A, Stepanchuk, O.V., \& Krotov, R.V. (2015). Doslidzhennya transportnykh potokiv $v$ aspektakh zatorovykh staniv dorozhn'oho rukhu [Investigation of traffic flows in the aspect of traffic congestion]. Kyyiv: NAU. [In Ukrainian]

Google Scholar

20. Polishchuk, A.I., \& Antonyak, H.L. (2019). Accumulation of heavy metals in gametophytes of the epilithic mosses. Studia Biologica, 13(2), 21-28.

Crossref $\bullet$ Google Scholar

21. Qarri, F., Lazo, P., Allajbeu, S., Bekteshi, L., Kane, S., \& Stafilov, T. (2019). The evaluation of air quality in Albania by moss biomonitoring and metals atmospheric deposition. Archives of Environmental Contamination and Toxicology, 76, 554-571.

Crossref $\bullet$ PubMed $\bullet$ Google Scholar

22. Raggio, J., Pintado, A., Vivas, M., Sancho, L.G., Büdel, B., Colesie, C., Weber, B., Schroeter, B., Lazáro, R., \& Green, T.G.A. (2014). Continuous chlorophyll fluorescence, gas exchange and microclimate monitoring in a natural soil crust habitat in Tabernas badlands, Almeria, Spain: progressing towards a model to understand productivity. Biodiversity and Conservation, 23(7), 1809-1826.

Crossref $\bullet$ Google Scholar

23. Rath, A., \& Das, A.B. (2021). Chromium stress induced oxidative burst in Vigna mungo (L.) Hepper: physio-molecular and antioxidative enzymes regulation in cellular homeostasis. Physiology and Molecular Biology of Plants, 27(2), 265-279.

Crossref $\bullet$ PubMed $\bullet$ Google Scholar

ISSN 1996-4536 (print) • ISSN 2311-0783 (on-line) • Біологічні Студії / Studia Biologica • 2021 • Том 15 / № 3 • С. 51-60 
24. Shabanda, I.S., Koki, I.B., Low, K.H., Zain, S.M., Khor, S.M., \& Abu Bakar, N.K. (2019). Daily exposure to toxic metals through urban road dust from industrial, commercial, heavy traffic, and residential areas in Petaling Jaya, Malaysia: a health risk assessment. Environmental Science and Pollution Research International, 26(36), 37193-37211.

Crossref $\bullet$ PubMed $\bullet$ Google Scholar

25. Shahid, M., Pourrut, B., Dumat, C., Nadeem, M., Aslam, M., \& Pinelli, E. (2014). Heavy-metalinduced reactive oxygen species: phytotoxicity and physicochemical changes in plants. Reviews of Environmental Contamination and Toxicology, 232, 1-44.

Crossref $\bullet$ PubMed $\bullet$ Google Scholar

26. Shahzad, B., Tanveer, M., Che, Z., Rehman, A., Cheema, S.A., Sharma, A., Song, H., Rehman, S.U., \& Zhaorong, D. (2018). Role of 24-epibrassinolide (EBL) in mediating heavy metal and pesticide induced oxidative stress in plants: A review. Ecotoxicology and Environmental Safety, 147, 935-944.

Crossref $\bullet$ PubMed $\bullet$ Google Scholar

27. Smith, A.J.E., \& Smith, R. (2004). The Moss Flora of Britain and Ireland (2nd ed.). Cambridge: Cambridge University Press.

Crossref • Google Scholar

28. Stanković, J.D., Sabovljević, A.D., \& Sabovljević, M.S. (2018). Bryophytes and heavy metals: a review. Acta Botanica Croatica, 77(2), 109-118.

Crossref $\bullet$ Google Scholar

29. Vanderpoorten, A., Papp, B., \& Gradstein, R. (2010). Sampling of bryophytes. In Eymann J., Degreef J., Häuser Ch., Monje J.C., Samyn Y., Spiegel D.V. (Eds.), Manual on Field Recording Techniques and Protocols for All Taxa Biodiversity Inventories (Chapter 13, pp. 331-345). ABC Taxa, Belgium.

Google Scholar

30. Vaskin, R.A., \& Vaskina, I.V. (2009). Analiz dynamiky zabrudnennya atmosfernoho povitrya Ukrayiny vykydamy avtotransportu [Analysis of the dynamics of atmospheric air pollution in Ukraine by motor vehicle emissions]. Bulletin of the Kremenchuk State Polytechnic University, 5(58), 109-112. [In Ukrainian]

Google Scholar

31. Welham, S.J., Gezan, S.A., Clark, S.J., \& Mead, A. (2014). Statistical methods in biology: design and analysis of experiments and regression. Florida: CRC Press.

Crossref $\bullet$ Google Scholar

32. Varela, Z., Debén, S., Saxena, D., Aboal, J., \& Fernández, J. (2018). Levels of antioxidant compound glutathione in moss from industrial areas. Atmosphere, 9(7), 284.

Crossref $\bullet$ Google Scholar

33. Wiłkomirski, B., Sudnik-Wójcikowska, B., Galera, H., Wierzbicka, M., \& Malawska, M. (2011). Railway transportation as a serious source of organic and inorganic pollution. Water, Air, \& Soil Pollution, 218(1-4), 333-345.

Crossref • PubMed • PMC • Google Scholar

34. Yaylalı-Abanuz, G. (2019). Application of multivariate statistics in the source identification of heavy-metal pollution in roadside soils of Bursa, Turkey. Arabian Journal of Geosciences, 12(12), 382.

Crossref $\bullet$ Google Scholar

35. You, J., \& Chan, Z. (2015). ROS regulation during abiotic stress responses in crop plants. Frontiers in Plant Science, 6, 1092.

Crossref $\bullet$ PubMed $\bullet$ PMC $\bullet$ Google Scholar

36. Zhang, H., Wang, Z., Zhang, Y., Ding, M., \& Li, L. (2015). Identification of traffic-related metals and the effects of different environments on their enrichment in roadside soils along the Qinghai-Tibet highway. Science of the Total Environment, 521-522, 160-172.

Crossref • PubMed • Google Scholar

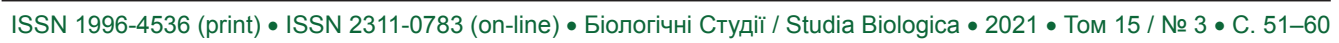




\title{
НАКОПИЧЕННЯ ВАЖКИХ МЕТАЛІВ І СИСТЕМА АНТИОКСИДАНТНОГО ЗАХИСТУ В ГАМЕТОФITI DIDYMODON RIGIDULUS HEDW. У РАЙОНАХ 3 ВИСОКИМ ТРАНСПОРТНИМ НАВАНТАЖЕННЯМ
}

\author{
О. І. Поліщук, Г. Л. Антоняк \\ Львівський національний університет імені Івана Франка \\ вул. Саксаганського, 1, Львів 79005, Україна
}

Обґрунтування. Різні види транспорту належать до основних джерел забруднення довкілля важкими металами та іншими забруднювачами. Відомо, що бріофіти накопичують важкі метали; проте метаболічні зміни в цих рослинах за умов акумуляції металів вивчені недостатньо. Метою статті було проаналізувати акумуляцію важких металів, процес пероксидного окиснення ліпідів (ПОЛ) і активність ензимів антиоксидантної системи в гаметофріті моху Didymodon rigidulus Hedw., зібраного в міських районах з інтенсивним рухом автомобільного та залізничного транспорту.

Матеріали і методи. Пагони моху збирали на трьох ділянках у місті Львові (Україна). Ділянку 1 (контроль) вибрали в парковій зоні; ділянки 2 і 3 - в районах з інтенсивним автомобільним і залізничним рухом відповідно. Концентрацію хрому $(\mathrm{Cr})$, нікелю (Ni), свинцю (Pb) та цинку $(\mathrm{Zn})$ в рослинному матеріалі визначали методом атомно-абсорбційної спектрофоотометрії. Рівень продуктів ПОЛ, а саме гідропероксидів ліпідів і речовин, які реагують з тіобарбітуровою кислотою (ТБК-активні продукти), а також супероксиддисмутазну (СОД) і каталазну активність визначали стандартними методами. Результати опрацьовували методами варіаційної статистики.

Результати. За рівнем акумуляції в гаметофріті моху D. rigidulus, зібраного у парковій зоні (ділянка 1), досліджувані метали можна розташувати в такому порядку: $\mathrm{Zn>} \mathrm{Cr>} \mathrm{Ni>} \mathrm{Pb.} \mathrm{У} \mathrm{пагонах} D$. rigidulus, зібраних на ділянці 2, виявлено більший рівень накопичення $\mathrm{Pb}, \mathrm{Zn}$ i Ni (у 2,27, 1,78 та 1,45 разу відповідно), а на ділянці 3 - вищий вміст $\mathrm{Pb}$ і Zn (в 1,8 та 1,67 разу відповідно) порівняно з рослинами, зібраними в парковій зоні. У зразках моху з цих ділянок не виявлено істотних відмінностей у концентрації $\mathrm{Cr}$ порівняно з контролем. Концентрація гідропероксидів ліпідів у пагонах моху, відібраних на ділянках 2 і 3, була відповідно в 4,26 і 3,75 разу більша від контролю, а утворення ТБК-активних продуктів було інтенсивнішим у рослинному матеріалі з ділянки 2, ніж з контрольної ділянки. СОД і каталазна активність була вірогідно більшою в пагонах D. rigidulus з ділянки 2 порівняно з контрольною ділянкою, проте активність обох фрерментів у зразках моху з ділянки 3 істотно не перевищувала контрольний рівень.

Висновки. Результати дослідження свідчать, що навантаження на навколишнє середовище, створюване автомобільним і залізничним транспортом, сприяє накопиченню важких металів, особливо $\mathrm{Zn}$ і $\mathrm{Pb}$, у гаметофіті моху D. rigidulus. За таких умов у клітинах $D$. rigidulus зростає інтенсивність процесів ПОЛ, що виразніше виявляється у пагонах моху на ділянці з інтенсивним автомобільним рухом. Активація антиоксидантних ензимів (СОД і каталази), виявлена в клітинах моху, що росте на цій ділянці, може відігравати важливу роль у захисті клітин бріофітів від оксидативного стресу, спричиненого накопиченням важких металів.

Ключові слова: бріофіти, Didymodon rigidulus, важкі метали, антиоксидантна система, пероксидне окиснення ліпідів, урбоекосистеми 29 September, 2021 